See discussions, stats, and author profiles for this publication at: https://www.researchgate.net/publication/295252922

\title{
Mineral metabolism of pregnant goats under feed restriction
}

Article in Animal Production Science · February 2016

DOI: 10.1071/AN14471

\section{CITATIONS}

0

9 authors, including:

$$
\text { Douglas Castagnino }
$$

Nutreco Canada Inc., Saint-Hyacinthe, Canada

28 PUBLICATIONS 169 CITATIONS

SEE PROFILE

Kleber Tomás de Resende

São Paulo State University

130 PUBLICATIONS 875 CITATIONS

SEE PROFILE

\section{READS}

75

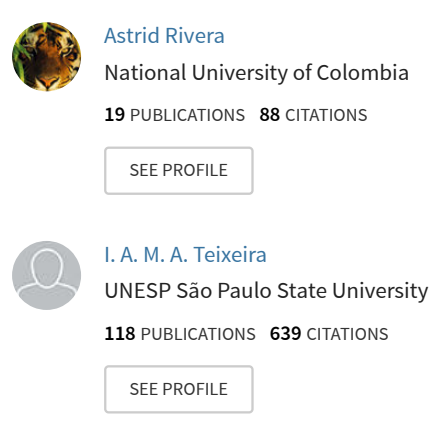

Some of the authors of this publication are also working on these related projects:

Growig goats metabolism View project

Prediction of the chemical composition of the forage Cenchrus clandestinus using Near Infrared Spectroscopy - NIRS View project 


\title{
Mineral metabolism of pregnant goats under feed restriction
}

\author{
Carla J. Härter ${ }^{\mathrm{A}}$, Lisiane D. Lima ${ }^{\mathrm{A}}$, Douglas S. Castagnino ${ }^{\mathrm{A}}$, Astrid R. Rivera ${ }^{\mathrm{A}}$, \\ Alana M. Nunes ${ }^{\mathrm{A}}$, Samuel F. Sousa ${ }^{\mathrm{A}}$, Annette Liesegang ${ }^{\mathrm{B}, \mathrm{C}}$, Kleber T. Resende ${ }^{\mathrm{A}}$ \\ and Izabelle A. M. A. Teixeira ${ }^{\mathrm{A}, \mathrm{D}}$ \\ AUNESP, Univ Estadual Paulista, Department of Animal Sciences, Jaboticabal, SP, Brazil 14884-900. \\ ${ }^{B}$ Institute of Animal Nutrition, University of Zurich, Zurich, $\mathrm{CH}-8057$, Switzerland. \\ ${ }^{C}$ CABMM, Centre for Applied Biotechnology and Molecular Medicine, University of Zurich, Switzerland. \\ ${ }^{D}$ Corresponding author. Email: izabelle@fcav.unesp.br
}

\begin{abstract}
We examined the effects of feed restriction on calcium, phosphorus, magnesium, sodium and potassium metabolism in Oberhasli and Saanen goats during gestation. The 63 goats were distributed into groups that were divided into three levels of feed restriction $(0 \%, 20 \%$ and $40 \%$ restriction) and slaughtered at different pregnancy stages $(80,110$ and 140 days of gestation), in a randomised block design with a $2 \times 3 \times 3$ factorial arrangement. The mineral balance was determined at $\sim 80,110$ and 140 days of gestation. The serum levels of minerals and alkaline phosphatase activity were determined during pregnancy. Mineral retention in the maternal body, femur, empty uterus, mammary gland, fetus and fetal fluid was also determined during gestation. Bone mineral density was measured in the femur. Mixed models with days of gestation, levels of feed restriction, breed and their interactions as fixed effects and blocks as random effect were used for data analysis. In response to the reduction in feed intake, the maternal body uses its mineral reserves to maintain gestation. Physiological adjustments of the goats subjected to $20 \%$ feed restriction avoided a decrease in fetal mineral deposition. More severe feed restriction, however, compromised concentrations of phosphorus, sodium and potassium in the fetus, which were the main minerals used by the maternal body, whereas calcium and magnesium deposition in fetuses remained unaffected. At 40\% feed restriction, the retention of all minerals in the body decreased, and the fetal dry mass was on average also less than those fetuses from goats without feed restriction. The fetal deposition of phosphorus, sodium and potassium was also lower during $40 \%$ restriction.
\end{abstract}

Additional keywords: gestation, fetal mineral deposition, maternal body, mineral retention, undernutrition.

Received 3 April 2014, accepted 26 September 2015, published online 18 February 2016

\section{Introduction}

Goat husbandry for milk and meat production contributes considerably to reducing world hunger, especially in India and countries in Africa and Asia, which have the largest herds (FAO 2005). Goat herds are known to survive in harsh environments such as deserts, semiarid areas and mountain regions (Devendra 1999), where animals often undergo food restriction. Feed deprivation (food shortages in harsh regions, seasonal variation in food availability or even nutritional management strategy), is one of the major nutritional challenges for animals.

The effects of feed restriction can be more serious if it is associated with specific physiological conditions such as pregnancy. Prolonged and severe feed restriction may compromise fetal development, especially at the end of pregnancy when the growth rate of the fetus is greater (Breier 2006). Moreover, the emergence of obesity, type II diabetes, hypertension, cardiovascular diseases, metabolic and behavioural disorders, underdevelopment of the gastrointestinal tract and low feed consumption have been reported in individuals born to mothers subjected to severe nutrient restriction during gestation (Trahair et al. 1997; Laporte-Broux et al. 2012).

In general, malnourishment during pregnancy primarily affects the mother because nutrients are mostly delivered to the fetus, and mobilisation of maternal deposits causes maternal weight loss and decreases energy uptake by the uterus (Bell and Ehrhardt 2000; Greenwood and Bell 2003). Studies on the fetal growth of sheep and cattle that investigate the consequences of feed restriction at the beginning and in the last third of pregnancy (Breier 2006; Long et al. 2009; Demirtas and Özcan 2012) have focussed mainly on maternal energy and protein metabolism (Bell and Ehrhardt 2000). Fetal growth and mineral metabolism in pregnant goats under feed restriction are quite different from that of cattle and sheep, and despite the importance of this information, it has been scarcely investigated (Van Soest 1994; Wilkens et al. 2014). Moreover, although the mineral requirements of goats are affected by genotype (Teixeira et al. 2013), studies comparing dairy goat breeds are nonexistent. Therefore, the objective of the present study was to evaluate the effects of feed restriction on maternal calcium $(\mathrm{Ca})$, phosphorus $(\mathrm{P})$, magnesium $(\mathrm{Mg})$, 
sodium $(\mathrm{Na})$ and potassium $(\mathrm{K})$ metabolism and on the deposition of these minerals in fetuses of Oberhasli and Saanen goats during pregnancy.

\section{Materials and methods}

\section{Animals, diet and experimental design}

The experimental procedures were previously approved by the Ethics Committee of São Paulo State University in Jaboticabal (\#026167-07). The 63 tested Oberhasli $(n=31)$ and Saanen $(n=32)$ goats were multiparous (from 2 to 3 years of age on average), non-lactating and non-pregnant. The initial bodyweight (BW) was on average $45.1 \pm 1.1 \mathrm{~kg}$ and $52.2 \pm$ $1.6 \mathrm{~kg}$ for Oberhasli and Saanen goats, respectively. The body condition scores were $2.38 \pm 0.09$ and $2.87 \pm 0.1 .4$ for Oberhasli and Saanen goats, respectively, which were within the normal range of 5 levels (1 to 5) with halves, was mainly based on palpation of sternum subcutaneous adipose tissue.

At the beginning of the experiment, four Oberhasli and five Saanen goats were slaughtered to estimate the initial body composition of non-pregnant goats, which served as a baseline to compare to values obtained from pregnant goats.

Concerning reproductive management, the goats were naturally mated after oestrus detection during the oestrus period. Oestrus was also induced by hormonal treatment in the anestrous periods as recommended by Freitas et al. (1996) and Ritar et al. (1984), in which vaginal sponges impregnated with medroxyprogesterone (medroxyprogesterone acetate, $60 \mathrm{mg}$ ) were introduced into the goats; after 5 days, the sponges were removed and $0.5 \mathrm{~mL}$ of Prolise, (ARSA S.R.L., Buenos Aires, Argentina) a synthetic analogue of PGF2 $\alpha$, and $2.0 \mathrm{~mL}$ of equine chorionic gonadotropin were administered. Oestrus was observed, on average, after $48 \mathrm{~h}$, and then the females were mated. The study was arranged in a completely randomised block design, using a $2 \times 3 \times 3$ factorial scheme that combined two breeds, three slaughter ages and three feeding regimes. Feed restriction started at Day 35 of pregnancy, when the number of fetuses was identified by sonography, and lasted until the pre-established day of the slaughter. As such, 54 twin pregnant goats (27 Saanen and 27 Oberhasli) with similar BW were randomly divided into three groups (nine goats of each breed per group) according to slaughter age (80, 110 and 140 days of gestation). Each group was divided into three blocks with three animals, and each goat in a block was subjected to a different feeding regime [no restriction (0\%), 20\% and 40\% feed restriction]. Animals without feed restriction were fed ad libitum, with the feed amount adjusted to allow 15\% orts. The amount of feed offered daily to the animals subjected to $20 \%$ and $40 \%$ feed restriction was based on the amount of food consumed by the goats fed ad libitum the previous day.

The goats were held in individual $1.0-\mathrm{m}^{2}$ pens equipped with a feeder and water trough. The diet was balanced according to the NRC (2007) requirements for pregnant goats. The diet was provided twice a day, at 0730 hours and 1700 hours. The diet composition is shown in Table 1. After mating, the animals were weighed every 15 days.

\section{Sampling}

The goats were slaughtered at 80,110 or 140 days of gestation, according to the treatment. The BW was measured immediately before slaughter, without previous water or feed deprivation. Goats were stunned using captive bolt pistol before being killed, and their blood was collected and stored for subsequent analysis. The pregnant uterus and mammary gland were the first organs removed. The components of the gravid uterus were separated into empty uterus (uterine tissue with placenta and placentomes), and fetuses and fetal fluid, which contained a combination of amniotic and allantoic fluids. The uterus components and mammary glands were weighed and frozen. The gastrointestinal tract (GIT) was then removed and weighed $(\mathrm{kg})$, with the GIT content weight $(\mathrm{kg})$ representing the difference between the full and empty GIT. The empty bodyweight (EBW) was calculated by subtracting the weight of the GIT content, urinary bladder and gallbladder from the BW immediately before slaughter.

The right femur was removed from the dead goats to measure the mineral density and mineral composition of the bones. The bone mineral density was determined from the radiographs of femur samples, taken by a SiemensTridoro 812E X-ray machine (Siemens, São Paulo, Brazil). The maternal body (MB; carcass, blood, organs, viscera, fat, head, limbs and skin) was ground and

Table 1. Feed and diet composition

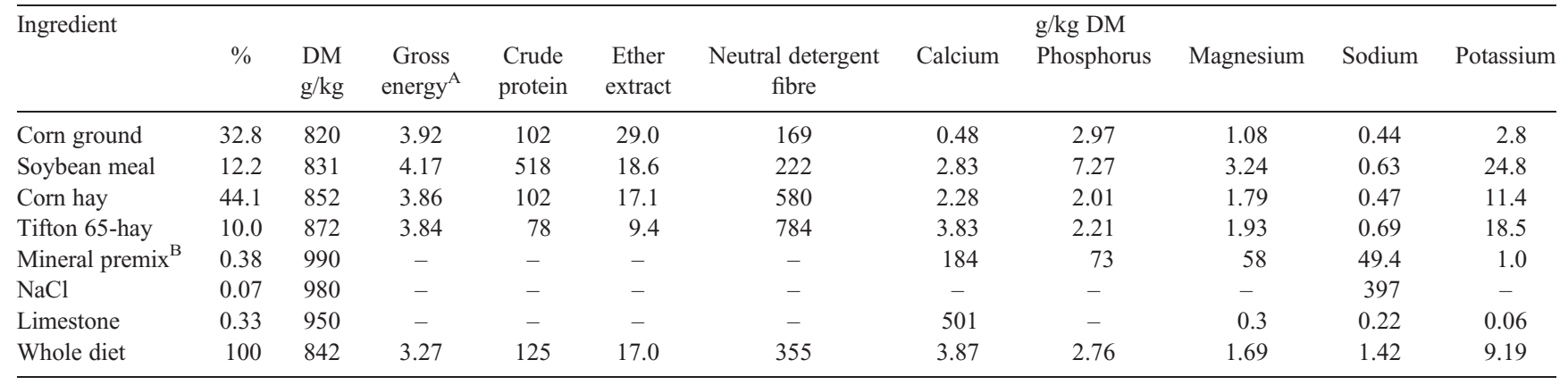

\footnotetext{
${ }^{\mathrm{A}}$ Gross energy in Mcal/kg of DM.

${ }^{\mathrm{B}}$ Premix contained $73 \mathrm{~g}$ of $\mathrm{P} / \mathrm{kg}, 190 \mathrm{~g}$ of Ca/kg, $62 \mathrm{~g}$ of Na/kg, $90 \mathrm{~g}$ of Cl$/ \mathrm{kg}, 44 \mathrm{~g}$ of Mg/kg, $30 \mathrm{~g}$ of S/kg, $1.35 \mathrm{mg} \mathrm{of} \mathrm{Zn/kg,} 340 \mathrm{mg}$ of Cu/kg, $940 \mathrm{mg}$ of $\mathrm{Mn} / \mathrm{kg}, 1.06 \mathrm{mg}$ of Fe/kg, $3 \mathrm{mg}$ of Co/kg, $16 \mathrm{mg}$ of I/kg, $10 \mathrm{mg}$ of Se $/ \mathrm{kg}$, maximum of $730 \mathrm{mg}$ of F/ kg.
} 
homogenised. A 1-kg sample of the MB was separated and frozen for further analysis of minerals. The empty uterus, fetuses, mammary glands and femur of the goats were also ground and homogenised and samples of these tissues were kept separated for future mineral analyses. The samples were freeze-dried for $72 \mathrm{~h}$. The body, mammary gland and femur samples were then defatted and analysed to determine mineral content.

The set of goats slaughtered at 140 days of gestation were used for periodical blood sampling (at 1, 35, 50, 65, 80, 95, 110, 125 and 140 days of gestation), before morning feeding. The blood samples were collected from the jugular vein in $10-\mathrm{mL}$ vacuum tubes without anticoagulant and allowed to clot. Thereafter, the serum was separated by centrifugation $(1370 \mathrm{~g}$; $20 \mathrm{~min} ; 4^{\circ} \mathrm{C}$ ) and stored at $-20^{\circ} \mathrm{C}$ until analysis.

\section{Digestibility trial}

The set of goats slaughtered at 140 days of gestation were previously subjected to three digestibility assays during pregnancy. To that end, they were placed in metabolism cages with controlled feed and ort, and total faeces and urine were collected for 5 days after 2 days of adjustment to the environment. The assays were performed at 80, 110 and 140 days of pregnancy. A total of $20 \%$ of the excreted faeces was collected, producing a 5-day composite. Urine was collected in buckets containing $50 \mathrm{~mL}$ of $7.2 \mathrm{~N} \mathrm{H}_{2} \mathrm{SO}_{4}$, and a $10 \%$ aliquot was removed daily and frozen for further analysis. The apparent absorption was defined as the mineral fraction that was ingested but not excreted in the faeces. The mineral balance was calculated by subtracting the content eliminated in the faeces and urine from the amount ingested. Leftover faeces, feed and feed samples were dried in a forced air oven at $55^{\circ} \mathrm{C}$ for $72 \mathrm{~h}$.

\section{Chemical analyses}

The bone mineral density was estimated in the proximal and distal femoral epiphysis and in the femoral diaphysis using $\mathrm{X}$-ray images and a 12-point scale for estimating the aluminium concentration (aluminium alloy 6063, ABNT 2005), as described by Araújo et al. (2011).

The DM and fat content in the samples of feed ingredients, leftovers, faeces, empty body, mammary gland, fetus, femur, empty uterus and fetal fluid were determined according to Association of Official Analytical Chemists (AOAC) methods 930.15 and 920.39, respectively (AOAC 1990). Because of the high fat content in the mammary gland, empty body and femur, ether extract analysis was adapted by defatting these samples with reflow in petroleum ether for $8 \mathrm{~h}$. The feed samples were analysed for total ash by combustion at $600^{\circ} \mathrm{C}$ for $3 \mathrm{~h}$, according to method 942.05 (AOAC 1990) and for crude protein by nitrogen $(\mathrm{N})$ determination with a Leco-FP 528 LC using the Dumas method, as described by Etheridge et al. (1998). The neutral detergent fibre (NDF) in the diet ingredients was determined by the method described by Robertson and Van Soest (1981). The gross energy density was obtained using a calorimetry bomb.

The mineral content in the empty body, femur, fetus, empty uterus, fetal fluid, mammary gland, feed ingredients, feed leftovers, faeces and urine was determined by digestion in nitric $\left(\mathrm{NHO}_{3}\right)+$ perchloric $\left(\mathrm{HClO}_{4}\right)(\mathrm{AOAC} 1990$; method 935). The calcium $(\mathrm{Ca})$ and magnesium $(\mathrm{Mg})$ concentration were measured by atomic absorption (AOAC 1990; method 935), sodium $(\mathrm{Na})$ and potassium $(\mathrm{K})$ by atomic emission (Fritz and Schenk 1979) and phosphorus (P) by colourimetric assays (AOAC 1990; method 935).

The serum $\mathrm{Ca}, \mathrm{P}$ and $\mathrm{Mg}$ levels $(\mathrm{mmol} / \mathrm{L})$ and alkaline phosphatase (ALP) activity (U/L) were determined by colourimetric procedures, using commercial kits (LABTEST, Lagoa Santa MG, Brazil) with spectrophotometry (model Bio 2000 LABQUEST to TABTEST). A ROCHE 9180 electrolyte analyser (Roche Diagnostics, Mannheim, Germany) was used to determine the serum $\mathrm{K}, \mathrm{Na}$ and ionised $\mathrm{Ca}$.

\section{Equations to predict body composition at conception}

Six structures were considered for the calculation of mineral retention: $\mathrm{MB}$, fetuses, fetal fluid, empty uterus, mammary gland and femur. The MB at slaughter was calculated by subtracting the sum of the weights of the gravid uterus and mammary glands from the EBW (Eqn 1).

$$
\begin{aligned}
\mathrm{MB}=\mathrm{EBW}- & (\text { gravid uterus weight } \\
& + \text { mammary gland weight })
\end{aligned}
$$

The fresh mass retention was obtained from the difference between the maternal BW, mammary gland weight, empty uterus weight and femur weight at slaughter time and their weights at the beginning of pregnancy, estimated from baseline animals [Eqns (2) to (8)]. Changes in bone mineral density were estimated using a similar procedure [Eqns (9) to (13)].

$$
\mathrm{EBWi}=-11.438 \pm 4.41+1.09 \pm 0.07 \times \mathrm{BW} \text { at mating }
$$

where, EBWi = initial empty BW $(\mathrm{kg}) ; \mathrm{BW}=$ bodyweight $(\mathrm{kg})$ at mating, with $R^{2}=0.96$, root mean square error (RMSE) = 2.25 and $P<0.0001$

$$
\mathrm{MBi}=0.32 \pm 0.56+0.982 \pm 0.01 \times \mathrm{EBWi}
$$

where, $\mathrm{MBi}=$ initial maternal bodyweight $(\mathrm{kg})$, with $R^{2}=$ 0.99, RMSE $=0.26$ and $P<0.0001$

$$
\begin{aligned}
\text { Initial gland }=- & 110.4 \pm 95.5+9.80 \pm 1.85 \\
& \times \operatorname{MBi}(\text { Oberhasli }) \\
\text { Initial gland }=- & 110.4 \pm 95.5+10.2 \pm 2.29 \\
& \times \operatorname{MBi}(\text { Saanen })
\end{aligned}
$$

where, initial gland $=$ initial mammary gland weight $(\mathrm{g})$, with $R^{2}=0.76$, RMSE $=80.27$ and $P=0.0017$

$$
\text { Initial uterus }=(\mathrm{EBWi}-\mathrm{MBi})-\text { initial gland }
$$

where, initial uterus $=$ initial empty uterus weight $(\mathrm{g})$.

$$
\begin{gathered}
\text { Initial femur }=0.72 \pm 0.06-0.0079 \pm 0.001 \times \\
\text { MBi }(\text { Oberhasli }) \\
\text { Initial femur }=0.72 \pm 0.06-0.0084 \pm 0.001 \\
\times \text { MBi }(\text { Saanen })
\end{gathered}
$$


where, initial femur $=$ initial femur weight $(\mathrm{g})$, with $R^{2}=0.83$, RMSE $=0.04$ and $P=0.0003$

Initial BMD of diaphysis $=$

$$
1.40 \pm 1.21+0.018 \pm 0.0003 \times \mathrm{MBi}(\text { Oberhasli) }
$$

Initial BMD of diaphysis $=$

$$
1.40 \pm 1.21+0.015 \pm 0.0004 \times \operatorname{MBi}(\text { Saanen })
$$

where, initial BMD of diaphysis = initial bone mineral density of diaphysis in the femur (mm aluminium), with $R^{2}=0.79$, RMSE $=0.75$ and $P=0.0019$

Initial BMD of proximal epyphysis $=$

$$
12.8 \pm 2.09-0.045 \pm 0.01 \times \text { FWi (Oberhasli) }
$$

Initial BMD of proximal epyphysis $=$

$$
12.8 \pm 2.09-0.050 \pm 0.01 \times \text { FWi (Saanen) }
$$

where, initial BMD of proximal epiphysis = initial bone mineral density of proximal epiphysis in the femur ( $\mathrm{mm}$ aluminium); $\mathrm{FWi}=$ initial femur weight (Eqns 7 and 8), with $R^{2}=0.61$, RMSE $=0.65$ and $P=0.015$

$$
\begin{aligned}
& \text { Initial BMD of distal epyphysis }= \\
& 7.24 \pm 2.07+0.002 \pm 0.0006 \times \mathrm{MBi}
\end{aligned}
$$

where, initial BMD of distal epiphysis = initial bone mineral density of distal epiphysis in the femur ( $\mathrm{mm}$ aluminium); $\mathrm{MBi}=$ initial maternal bodyweight $(\mathrm{kg})$, with $R^{2}=0.40$, RMSE $=1.38$ and $P=0.05$.

The dry mass and minerals retention were obtained from the difference between the composition of the MB, empty uterus, fetuses, fetal fluids, mammary gland, and femur at slaughter time and their composition at the beginning of pregnancy. The dry mass at the beginning of pregnancy of the $\mathrm{MB}$ was significantly correlated with the initial MB weight (Eqn 14). The dry mass of the empty uterus, mammary gland, and femur were considered $17.8 \%, 42.6 \%$, and $83.2 \%$ of their fresh weights, respectively.

$$
\mathrm{Dmi}=22.9 \pm 8.13+0.549 \pm 0.164 \mathrm{MBi}
$$

where, $\mathrm{Dmi}=$ dry mass of the MB at the beginning of pregnancy (\%), with $R^{2}=0.62$, RMSE $=3.55$ and $P=0.0124$.

Because we did not find a significant regression correlated with the dry mass, the mineral compositions of the MB, empty uterus, mammary gland and femur at the beginning of pregnancy were estimated using the average compositions found in the baseline goats (Table 2). The compositions of the fetuses and fetal fluid at the beginning of pregnancy were assigned a value of zero.

\section{Statistics}

To estimate the fresh weight at the beginning of pregnancy, we obtained regression equations for $\mathrm{MB}$, empty uterus, mammary gland, femur, and femur bone mineral density based on the baseline composition of non-pregnant goats. The calculations were performed using the SAS MIXED procedure of SAS (version 9.2, SAS Institute Inc., Cary, NC, USA). The analysis assessed the effects of breed on the regression models obtained. The dry mass and mineral composition of the MB, empty uterus, mammary gland, and femur at the beginning of pregnancy were estimated by regression against the fresh weight and dry mass, respectively. When the regression was not significant we used the average mineral compositions of the baseline goats.

The feed intake and mineral balance data were evaluated in a completely randomised block design with repeatedmeasures over time. Mixed models were applied with fixed effects for breed (1 d.f.), level of feed restriction ( 1 d.f.), days of gestation ( 2 d.f. for 80,110 and 140 days), the interaction of these factors and the random effects of block ( 2 d.f.) and the residual error, using the MIXED procedure of SAS (version 9.2). The covariance matrix that best fit the data according to the Bayesian information criterion was selected.

The statistical model was:

$$
\begin{gathered}
Y_{i j k l}=\mu+B_{i}+a_{j: i l}+R_{k}+D_{1}+\left(B_{i} \times R_{k}\right)+\left(B_{i} \times D_{1}\right) \\
+\left(R_{k} \times D_{1}\right)+\left(B_{i} \times R_{k} \times D_{1}\right)+\varepsilon_{i j k l}
\end{gathered}
$$

where, $\mu=$ overall intercept mean; $\mathrm{B}=$ effect of the breed $\mathrm{i}$; $\mathrm{a}=$ effect of the block $\mathrm{j} ; \mathrm{R}=$ effect of the restriction level k; $\mathrm{D}=$ effect of days of gestation 1; interactions; and $\varepsilon=$ error associated with each $Y_{\mathrm{ijkl}}$.

The mineral retention data were analysed by mixed models for breed ( 1 d.f.), days of gestation ( 2 d.f.), feed restriction level ( 2 d.f.) and the interaction of these factors ( 4 d.f.) as fixed effects and block ( 2 d.f.) and error as random effects, using the MIXED procedure of SAS (version 9.2). Residual variances, distinct to 'level of restriction' and 'days of gestation' subclasses, were modelled using the GROUP option of the REPEATED command.

The serum minerals and ALP activity were analysed in a completely randomised block design with repeated-measures over time. Mixed models were applied with breed (1 d.f.),

Table 2. Mineral composition (\% of dry mass) of the maternal body, empty uterus, mammary gland and femur at the beginning of pregnancy, estimated from baseline animals Mean \pm standard error of mean

\begin{tabular}{lcccc}
\hline Item & Maternal body & Empty uterus & Mammary gland & Femur \\
\hline Calcium & $2.95 \pm 0.212$ & $0.114 \pm 0.0092$ & $0.317 \pm 0.0856$ & $16.0 \pm 0.460$ \\
Phosphorus & $1.54 \pm 0.108$ & $0.726 \pm 0.0854$ & $0.420 \pm 0.0558$ & $7.09 \pm 0.431$ \\
Magnesium & $0.0805 \pm 0.0054$ & $0.062 \pm 0.0046$ & $0.033 \pm 0.0035$ & $0.305 \pm 0.020$ \\
Sodium & $0.250 \pm 0.0187$ & $1.29 \pm 0.0982$ & $0.463 \pm 0.0671$ & $0.490 \pm 0.036$ \\
Potassium & $0.286 \pm 0.0253$ & $0.970 \pm 0.121$ & $0.276 \pm 0.0466$ & $0.034 \pm 0.0049$
\end{tabular}


level of feed restriction ( 2 d.f.), days of gestation (8 d.f.), the interaction of these factors as fixed effects and the random effects of blocks ( 2 d.f.) and error, using the MIXED procedure of SAS (version 9.2). The covariance matrix that best fits the data according to the Bayesian information criterion was selected.

High-level interactions without statistical significance obtained in data analyses were sequentially removed. Significant means for days of gestation and levels of restriction were compared using Tukey's minimum significant difference (i.e. option PDIFF adjust $=$ Tukey of the LSMEANS command). Residual graphs were used to detect the violation of assumptions in ANOVA, such as variance heterogeneity, auto correlated error, and the presence of outliers. The significance level was set at $P \leq 0.05$. Trends were considered at $0.05 \leq P \leq 0.10$.

\section{Results}

\section{Intake, mineral availability and balance}

The mineral and DM intake decreased $(P<0.05)$ with feed restriction and decreased at the end of pregnancy $(P<0.01)$, from Day 110 of pregnancy to Day 140 (Table 3). The $\mathrm{Ca}$ $(P=0.07), \mathrm{P}$ and $\mathrm{K}(P<0.01)$ balances and $\mathrm{Na}$ losses $(P<0.01)$ in the goats decreased with an increase in the feed restriction level (Table 3). A decrease in the $\mathrm{P}(P=0.09)$ and an increase in the $\mathrm{Mg}(P<0.01)$ balances were also observed during pregnancy in all treatments.

The apparent availability (AA) of $\mathrm{Ca}$ decreased with increased feed restriction $(P=0.07)$, whereas the AA of $\mathrm{P}$ and $\mathrm{K}$ did not change. Additionally, the excretion in urine as a proportion of metabolic EBW of all of the minerals studied was similar among feed restrictions.

\section{Mineral retention}

The MB lost dry mass at $20 \%$ feed restriction and at $40 \%$ feed restriction $(P<0.01$; Table 4$)$. Similarly, the retention of almost all off the minerals decreased significantly in the body of goats subjected to $40 \%$ feed restriction, except for $\mathrm{K}$ retention $(P=0.06)$. During fetal development, $\mathrm{Ca}, \mathrm{P}$ and $\mathrm{Mg}$ retention in the MB decreased $(P<0.05)$. Additionally, Saanen goats exhibited negative $\mathrm{Ca}$ and $\mathrm{P}$ retention $(P<0.01)$. The interaction observed in $\mathrm{Na}$ retention in the MB means that Saanen goats subjected to $40 \%$ feed restriction had higher body $\mathrm{Na}$ losses $(P<0.05)$ than Oberhasli goats.

The dry mass of twin fetuses from goats subjected to $40 \%$ feed restriction was lower than that of fetuses from goats without feed restriction $(P<0.05$; Table 5). Similarly, at $40 \%$ of feed restriction, fetal $\mathrm{Na}(P=0.06)$ and $\mathrm{K}(P<0.05)$ retention decreased. The retention of all minerals in the fetuses and the fetuses' weights increased significantly with the increase of gestation days $(P<0.05)$.

The $40 \%$ feed restriction resulted in higher dry mass $(P<0.05)$ and $\mathrm{Na}$ retention $(P=0.06)$ in the fetal fluid (Table 5). The fetal fluid of Oberhasli goats had a higher retention of fresh fluid and water $(P<0.01)$ and a lower retention of $\mathrm{P}(P<0.05)$. With pregnancy development, the amount of fetal fluid retained and its concentrations of $\mathrm{P}, \mathrm{Mg}$ and $\mathrm{K}$ increased $(P<0.01)$. However, the interaction shows that at 110 days of pregnancy the $\mathrm{K}$ retention was higher in those goats fed with $40 \%$ feed restriction $(P<0.05)$.

Feed restriction did not affect mineral retention in the empty uterus (Table 5). Fresh mass, dry mass, $\mathrm{Mg}$, and $\mathrm{K}$ retention in the empty uterus increased during pregnancy development $(P<0.05)$.

The mammary gland dry weight $(P<0.05)$ and $\mathrm{K}$ $(P<0.01)$ retentions decreased $(P<0.01)$ with the feed restriction (Table 6). The interaction between feed restriction and gestation days affected $\mathrm{P}$ retention, which decreased at 80 days of gestation in feed restriction treatments $(P<0.01)$ in the mammary gland. This effect was limited to that period, and at 110 and 140 days of gestation, $P$ retention in the mammary gland did not differ among treatments. Additionally, the

Table 3. Mineral intake and balance in Oberhasli and Saanen goats at 80,110 and 140 days of gestation

a,b, Different letters on the same line indicate differences among feed restriction according to Tukey's test $(P<0.05)$. A,B,C, Different letters on the same line indicate differences among gestation days according to Tukey's test $(P<0.05)$. n.s., not significant $(P>0.10)$; *, $P<0.05 ; * *, P<0.01$. EBW ${ }^{0,75}$, metabolic empty bodyweight; s.e.m., standard error of least-squares means

\begin{tabular}{|c|c|c|c|c|c|c|c|c|c|c|c|c|c|c|}
\hline \multirow[t]{3}{*}{ Item } & \multicolumn{11}{|c|}{ Treatments } & \multicolumn{3}{|c|}{$P$-value } \\
\hline & \multicolumn{3}{|c|}{ Breed } & \multicolumn{4}{|c|}{ Feed restriction } & \multicolumn{4}{|c|}{ Days } & \multirow[b]{2}{*}{ Breed } & \multirow[b]{2}{*}{ Feed restriction } & \multirow[b]{2}{*}{ Days } \\
\hline & Oberhasli & Saanen & s.e.m. & 0 & 20 & 40 & s.e.m. & 80 & 110 & 140 & s.e.m. & & & \\
\hline \multicolumn{15}{|c|}{ Consumption (g/day.EBW $\left.W^{0.75}\right)$} \\
\hline $\mathrm{DM}$ & 44.0 & 48.9 & 3.02 & $53.9 \mathrm{a}$ & $46.3 \mathrm{ab}$ & $39.1 \mathrm{~b}$ & 3.74 & $46.6 \mathrm{~A}$ & $43.9 \mathrm{~A}$ & $33.0 \mathrm{~B}$ & 3.94 & n.s. & $*$ & $* *$ \\
\hline Calcium $^{\mathrm{A}}$ & 0.23 & 0.25 & 0.02 & $0.28 \mathrm{a}$ & $0.24 \mathrm{ab}$ & $0.19 \mathrm{~b}$ & 0.03 & $0.24 \mathrm{~A}$ & $0.23 \mathrm{~A}$ & $0.17 \mathrm{~B}$ & 0.02 & n.s. & $* *$ & $* *$ \\
\hline Phosphorus & 0.14 & 0.16 & 0.01 & $0.18 \mathrm{a}$ & $0.15 \mathrm{ab}$ & $0.13 b$ & 0.01 & $0.16 \mathrm{~A}$ & $0.15 \mathrm{~A}$ & $0.11 \mathrm{~B}$ & 0.01 & n.s. & $* *$ & $* *$ \\
\hline Magnesium & 0.08 & 0.09 & 0.005 & $0.10 \mathrm{a}$ & $0.08 \mathrm{ab}$ & $0.07 \mathrm{~b}$ & 0.007 & $0.08 \mathrm{~A}$ & $0.08 \mathrm{~A}$ & $0.06 \mathrm{~B}$ & 0.007 & n.s. & $*$ & $* *$ \\
\hline Sodium & 0.04 & 0.04 & 0.003 & $0.05 \mathrm{a}$ & $0.04 \mathrm{ab}$ & $0.04 \mathrm{~b}$ & 0.003 & $0.04 \mathrm{~A}$ & $0.04 \mathrm{~A}$ & $0.03 \mathrm{~B}$ & 0.004 & n.s. & $*$ & $* *$ \\
\hline Potassium & 0.43 & 0.48 & 0.03 & $0.52 \mathrm{a}$ & $0.45 \mathrm{ab}$ & $0.38 \mathrm{~b}$ & 0.04 & $0.45 \mathrm{~A}$ & $0.43 \mathrm{~A}$ & $0.32 \mathrm{~B}$ & 0.04 & n.s. & $*$ & $* *$ \\
\hline \multicolumn{15}{|c|}{ Balance $\left(m g / d a y . E B W^{0.75}\right)$} \\
\hline Calcium & 15.2 & 30.7 & 10.3 & $34.0 \mathrm{a}$ & $34.8 \mathrm{ab}$ & $-0.007 \mathrm{~b}$ & 12.4 & 32.0 & 11.7 & 25.1 & 14.1 & n.s. & 0.07 & n.s. \\
\hline Phosphorus & 71.3 & 91.7 & 10.9 & $107 \mathrm{a}$ & 77.3ab & $59.4 \mathrm{~b}$ & 12.3 & $107 \mathrm{~A}$ & $71.1 \mathrm{AB}$ & $66.7 \mathrm{~B}$ & 14.6 & n.s. & $* *$ & 0.09 \\
\hline Magnesium & -44.8 & -23.4 & 9.66 & -47.0 & -20.7 & -34.6 & 11.6 & $-58.6 \mathrm{~B}$ & $-31.7 \mathrm{AB}$ & $-11.9 \mathrm{~A}$ & 13.2 & 0.09 & n.s. & * \\
\hline Sodium & -61.3 & -66.2 & 21.4 & $-134 b$ & $-25.7 \mathrm{a}$ & $-31.0 \mathrm{a}$ & 25.5 & -67.4 & -79.6 & -44.0 & 29.1 & n.s. & $* *$ & n.s. \\
\hline Potassium & 173 & 255 & 42.2 & $345 \mathrm{a}$ & $188 \mathrm{ab}$ & $108 \mathrm{~b}$ & 46.2 & 284 & 218 & 139 & 57.3 & n.s. & $* *$ & n.s. \\
\hline
\end{tabular}

\footnotetext{
${ }^{\mathrm{A}}$ Interaction between breed and feed restriction $(P<0.05)$.
} 
Table 4. Mineral retention in the maternal body of feed-restricted Oberhasli and Saanen goats at 80,110 and 140 days of gestation a,b, Different letters on the same line indicate differences among feed restriction according to Tukey's test $(P<0.05)$. A,B,C, Different letters on the same line indicate differences among gestation days according to Tukey's test $(P<0.05)$. n.s., not significant $(P>0.10) ;{ }^{*}, P<0.05 ; * *, P<0.01$. s.e.m., standard error of least-squares means; BW, bodyweight; EBW, empty bodyweight; MBW, maternal bodyweight; AMBW, average maternal bodyweight; Ca, calcium; $\mathrm{P}$, phosphorus; Mg, magnesium; K, potassium; Na, sodium; B, Breed; R, feed restriction levels; D, gestation days



mammary gland fresh and dry weights and $\mathrm{Mg}$ and $\mathrm{K}$ retentions increased $(P<0.01)$ with pregnancy development (Table 6).

Saanen goats showed higher $\mathrm{Ca}, \mathrm{P}, \mathrm{Mg}(P<0.05)$ and $\mathrm{Na}$ $(P=0.06)$ retention in the femur (Table 7). The $\mathrm{P}$ deposition in the femur varied during pregnancy, and the highest retention was found at 110 days of gestation $(P<0.01)$.

The bone mineral densitometry retention of the distal epiphysis, proximal epiphysis and diaphysis was $-0.33 \pm$ $0.490,-1.865 \pm 0.250$ and $0.185 \pm 0.292$, respectively, and was not affected by any of the treatments.

\section{Blood measurements}

The serum Ca levels were higher in Saanen $(1.98 \pm 0.0424$ $\mathrm{mmol} / \mathrm{L})$ than in Oberhasli goats $(1.81 \pm 0.0449 \mathrm{mmol} / \mathrm{L}$; $P<0.05)$. Moreover, irrespective of breed and feed restriction, serum Ca levels decreased at 110 days of pregnancy $(P<0.01$; Fig. 1). ALP was not affected by breed and feed restriction, and its activity increased at Day 50 of pregnancy and then gradually decreased $(P<0.01$; Fig. 1$)$. Serum $\mathrm{Mg}$ levels were higher in Saanen goats than Oberhasli goats $(P<0.01)$ at 140 days gestation (Fig. 2). Feed restriction did not change serum minerals and ALP activity, except for K levels (Fig. 3), which were higher in Oberhasli goats fed ad libitum than in Saanen goats $(P<0.05)$.

\section{Discussion}

To the extent of our knowledge, this is the first study addressing the metabolism of $\mathrm{Ca}, \mathrm{P}, \mathrm{Mg}, \mathrm{Na}$ and $\mathrm{K}$ in pregnant dairy goats under feed restriction that shows the consequences for different pregnancy products. Our results may help guide nutrient management strategies for pregnant goats, highlighting the importance of mineral supplementation during periods of feed scarcity.

In the present study, a decrease of mineral balance was observed with feed restriction, probably because the intake of minerals decreased whereas their excretion remained the same after feed restriction. Despite expectations, we did not observe neither an increase in mineral AA nor differences in mineral excretion in the urine with the feed restriction. Our findings are in accordance with those reported by Kronqvist et al. (2011) in periparturient dairy cows. They found that $\mathrm{Ca}$ AA did not change with different levels of $\mathrm{Ca}$ intake; however, the $\mathrm{Ca}$ excretion in urine was greater in cows fed a lower amount of $\mathrm{Ca}$. These findings indicate that ruminant metabolism during pregnancy responds to mineral restriction by mobilising body reserves rather than increasing the AA. This theory can be supported by the decrease of mineral retention in the $\mathrm{MB}$ observed in this study. However, all of the mechanisms involved in these metabolic female responses are still not well known, and more studies are needed to identify them.

The mineral and mass retentions observed in the empty uterus indicate the ability of the MB to sustain fetal nutrition despite feed restriction. Furthermore, fetal growth can be directly related to the placental mass, with the uterus serving as the main mediator of nutrient transfer from mother to fetus (Hafez and Hafez 2000; Bell et al. 2005). However, the results of mineral femur retention observed in the present study did not indicate mineral mobilisation in the MB. Femur bone mineral density and retention have been successfully used to 
Table 5. Mineral retention in pregnant uterus components (fetuses, fetal fluid, and empty uterus) of feed-restricted Oberhasli and Saanen goats at 80,110 and 140 days of gestation

a,b, Different letters on the same line indicate differences among feed restriction according to Tukey's test $(P<0.05)$. A,B,C, Different letters on the same line indicate differences among gestation days according to Tukey's test $(P<0.05)$. n.s., not significant $(P>0.10) ; *, P<0.05 ; * *, P<0.01$. s.e.m., standard error of least-squares means; Ca, calcium; P, phosphorus; Mg, magnesium; K, potassium; Na, sodium; AFW, average femur weight; AFFW, average fetal fluid weight; AEUW, average empty uterus weight; B, Breed; R, feed restriction levels; D, gestation days

\begin{tabular}{|c|c|c|c|c|c|c|c|c|c|c|c|c|c|c|c|}
\hline \multirow[t]{3}{*}{ Item } & \multicolumn{11}{|c|}{ Treatments } & \multicolumn{4}{|c|}{$P$-value } \\
\hline & \multicolumn{3}{|c|}{ Breed } & \multicolumn{4}{|c|}{ Feed restriction } & \multicolumn{4}{|c|}{ Days } & \multirow[b]{2}{*}{ Breed } & \multirow[b]{2}{*}{$\begin{array}{c}\text { Feed } \\
\text { restriction }\end{array}$} & \multirow[b]{2}{*}{ Days } & \multirow[b]{2}{*}{ Interaction } \\
\hline & Oberhasli & Saanen & s.e.m. & 0 & 20 & 40 & s.e.m. & 80 & 110 & 140 & s.e.m. & & & & \\
\hline \multicolumn{16}{|c|}{ Fetuses } \\
\hline $\begin{array}{l}\text { Fetuses weight } \\
\quad(\mathrm{kg})\end{array}$ & 3.10 & 2.88 & 0.11 & 2.99 & 3.15 & 2.84 & 0.15 & $0.477 \mathrm{C}$ & $2.45 \mathrm{~B}$ & $6.05 \mathrm{~A}$ & 0.18 & n.s. & n.s. & $* *$ & n.s. \\
\hline AFW (g) & 1553 & 1441 & 54.8 & 1495 & 1574 & 1422 & 75.6 & $239 \mathrm{C}$ & 1227B & $3026 \mathrm{~A}$ & 91.6 & n.s. & n.s. & $* *$ & n.s. \\
\hline $\begin{array}{l}\text { Fresh mass } \\
\text { retention }(\mathrm{g})\end{array}$ & 3104 & 2883 & 109 & 2990 & 3149 & 2844 & 151 & $477 \mathrm{C}$ & $2453 B$ & $6052 \mathrm{~A}$ & 183 & n.s. & n.s. & $* *$ & n.s. \\
\hline $\begin{array}{l}\text { Dry mass } \\
\quad \text { retention }(\mathrm{g})\end{array}$ & 458 & 452 & 35.2 & $462 \mathrm{a}$ & $459 a$ & $445 b$ & 25.0 & $45.1 \mathrm{~B}$ & $354 \mathrm{~B}$ & $968 \mathrm{~A}$ & 54.3 & n.s. & $*$ & $* *$ & n.s. \\
\hline $\begin{array}{l}\text { Ca retention } \\
\quad(\mathrm{mg} / \mathrm{g} \mathrm{AFW})\end{array}$ & 13.5 & 13.3 & 0.67 & 13.3 & 14.7 & 12.2 & 1.12 & $8.24 \mathrm{C}$ & $14.1 \mathrm{~B}$ & $17.8 \mathrm{~A}$ & 1.31 & n.s. & n.s. & $* *$ & n.s. \\
\hline $\begin{array}{l}\text { P retention } \\
\qquad(\mathrm{mg} / \mathrm{g} \mathrm{AFW})\end{array}$ & 8.33 & 8.52 & 0.46 & $8.43 a$ & $9.76 a$ & $7.09 b$ & 0.78 & $5.64 \mathrm{~B}$ & $9.27 \mathrm{~A}$ & $10.4 \mathrm{~A}$ & 0.68 & n.s. & $*$ & $* *$ & n.s. \\
\hline $\begin{array}{l}\text { Mg retention } \\
\quad(\mathrm{mg} / \mathrm{g} \mathrm{AFW})\end{array}$ & 0.42 & 0.45 & 0.02 & 0.44 & 0.46 & 0.40 & 0.02 & $0.33 \mathrm{~B}$ & $0.45 \mathrm{~A}$ & $0.52 \mathrm{~A}$ & 0.03 & n.s. & n.s. & $* *$ & n.s. \\
\hline $\begin{array}{l}\text { Na retention } \\
\qquad(\mathrm{mg} / \mathrm{g} \text { AFW) }\end{array}$ & 3.96 & 4.32 & 0.27 & 4.37 & 4.46 & 3.59 & 0.35 & $3.48 \mathrm{~B}$ & $4.37 \mathrm{AB}$ & $4.56 \mathrm{~A}$ & 0.39 & n.s. & 0.06 & $*$ & n.s. \\
\hline $\begin{array}{l}\text { K retention } \\
\qquad(\mathrm{mg} / \mathrm{g} \mathrm{AFW})\end{array}$ & 2.83 & 2.91 & 0.13 & $2.99 \mathrm{ab}$ & $3.18 \mathrm{a}$ & $2.44 \mathrm{~b}$ & 0.13 & $2.28 \mathrm{~B}$ & $3.33 \mathrm{~A}$ & $3.00 \mathrm{~A}$ & 0.25 & n.s. & $*$ & $* *$ & n.s. \\
\hline \multicolumn{16}{|c|}{ Fetal fluid } \\
\hline AFFW (g) & 1154 & 898 & 53.9 & 1021 & 999 & 1059 & 66.7 & $736 \mathrm{C}$ & 988B & $1355 \mathrm{~A}$ & 65.0 & ** & n.s. & ** & n.s. \\
\hline $\begin{array}{l}\text { Fresh fluid } \\
\text { retention }(\mathrm{g})\end{array}$ & 2212 & 1876 & 76.4 & 2062 & 2055 & 2014 & 112 & $1408 \mathrm{C}$ & 1968B & $2755 \mathrm{~A}$ & 176 & $* *$ & n.s. & $* *$ & n.s. \\
\hline $\begin{array}{l}\text { Dry mass } \\
\quad \text { retention }(\mathrm{g})\end{array}$ & 39.5 & 27.8 & 3.32 & $29.4 b$ & $29.9 b$ & $41.6 \mathrm{a}$ & 2.70 & $24.1 \mathrm{~B}$ & $30.9 \mathrm{~B}$ & $45.9 \mathrm{~A}$ & 5.24 & $* *$ & $* *$ & $* *$ & n.s. \\
\hline $\begin{array}{l}\text { Ca retention } \\
\quad(\mathrm{mg} / \mathrm{g} \text { AFFW })\end{array}$ & 0.20 & 0.21 & 0.01 & 0.21 & 0.21 & 0.20 & 0.01 & 0.20 & 0.23 & 0.18 & 0.01 & n.s. & n.s. & n.s. & n.s. \\
\hline $\begin{array}{l}\text { P retention } \\
\qquad(\mathrm{mg} / \mathrm{g} \text { AFFW) }\end{array}$ & 0.07 & 0.10 & 0.01 & 0.09 & 0.08 & 0.09 & 0.01 & $0.05 \mathrm{~B}$ & $0.08 \mathrm{~B}$ & $0.12 \mathrm{~A}$ & 0.02 & $*$ & n.s. & $* *$ & n.s. \\
\hline $\begin{array}{l}\text { Mg retention } \\
\text { (mg/g AFFW) }\end{array}$ & 0.08 & 0.08 & 0.01 & 0.08 & 0.08 & 0.08 & 0.01 & $0.05 \mathrm{~B}$ & $0.08 \mathrm{AB}$ & $0.11 \mathrm{~A}$ & 0.01 & n.s. & n.s. & $* *$ & n.s. \\
\hline $\begin{array}{l}\text { Na retention } \\
\text { (mg/g AFFW) }\end{array}$ & 3.28 & 2.52 & 0.34 & 2.51 & 2.71 & 3.47 & 0.35 & 3.56 & 2.68 & 2.46 & 0.42 & n.s. & 0.06 & n.s. & n.s. \\
\hline $\begin{array}{l}\text { K retention } \\
\text { (mg/g AFFW) }\end{array}$ & 0.92 & 0.86 & 0.08 & 0.86 & 0.79 & 1.02 & 0.12 & $0.40 \mathrm{~B}$ & $0.98 \mathrm{~A}$ & $1.28 \mathrm{~A}$ & 0.14 & n.s. & n.s. & $* *$ & $\mathrm{R} \times \mathrm{D}^{*}$ \\
\hline \multicolumn{16}{|c|}{ Empty uterus } \\
\hline AEUW (g) & 1003 & 1037 & 62.2 & 1146 & 951 & 962 & 128 & $818 B$ & $1160 \mathrm{~A}$ & $1082 \mathrm{~A}$ & 77.6 & n.s. & n.s. & $* *$ & n.s. \\
\hline $\begin{array}{l}\text { Fresh mass } \\
\quad \text { retention }(\mathrm{g})\end{array}$ & 1714 & 1626 & 85.4 & 1810 & 1615 & 1585 & 163 & $1362 \mathrm{~B}$ & $1890 \mathrm{~A}$ & $1757 \mathrm{~A}$ & 120 & n.s. & n.s. & $* *$ & n.s. \\
\hline $\begin{array}{l}\text { Dry mass } \\
\quad \text { retention }(\mathrm{g})\end{array}$ & 219 & 220 & 15.9 & 227 & 231 & 200 & 22.2 & 173B & $231 \mathrm{~A}$ & $254 \mathrm{~A}$ & 23.3 & n.s. & n.s. & $*$ & n.s. \\
\hline $\begin{array}{l}\text { Ca retention } \\
\text { (mg/g AEUW) }\end{array}$ & 0.38 & 0.42 & 0.03 & 0.39 & 0.46 & 0.35 & 0.05 & 0.40 & 0.35 & 0.45 & 0.04 & n.s. & n.s. & 0.08 & n.s. \\
\hline $\begin{array}{l}\text { P retention } \\
\qquad(\mathrm{mg} / \mathrm{g} \text { AEUW) }\end{array}$ & 2.30 & 2.23 & 0.09 & 2.41 & 2.21 & 2.17 & 0.15 & 2.09 & 2.27 & 2.44 & 0.14 & n.s. & n.s. & n.s. & n.s. \\
\hline $\begin{array}{l}\text { Mg retention } \\
(\mathrm{mg} / \mathrm{g} \text { AEUW })\end{array}$ & 0.21 & 0.20 & 0.01 & 0.20 & 0.20 & 0.20 & 0.01 & $0.18 \mathrm{~B}$ & $0.20 \mathrm{AB}$ & $0.23 \mathrm{~A}$ & 0.01 & n.s. & n.s. & $*$ & n.s. \\
\hline $\begin{array}{l}\text { Na retention } \\
\quad(\mathrm{mg} / \mathrm{g} \text { AEUW) }\end{array}$ & 4.06 & 3.48 & 0.18 & 3.93 & 3.84 & 3.55 & 0.26 & 3.68 & 3.78 & 3.86 & 0.26 & $*$ & n.s. & n.s. & n.s. \\
\hline $\begin{array}{l}\text { K retention } \\
\quad(\mathrm{mg} / \mathrm{g} \text { AEUW) }\end{array}$ & 3.49 & 3.03 & 0.17 & 3.55 & 3.30 & 2.94 & 0.24 & $2.82 \mathrm{~B}$ & $3.02 \mathrm{~B}$ & $3.93 \mathrm{~A}$ & 0.28 & 0.07 & n.s. & $*$ & $\mathrm{~B} \times \mathrm{R} \times \mathrm{D}^{*}$ \\
\hline
\end{tabular}


Table 6. Mineral retention in the mammary gland of feed-restricted Oberhasli and Saanen goats at 80, 110 and 140 days of gestation $\mathrm{a}, \mathrm{b}$, Different letters on the same line indicate differences among feed restriction according to Tukey's test $(P<0.05)$. A,B,C, Different letters on the same line indicate differences among gestation days according to Tukey's test $(P<0.05)$. n.s., not significant $(P>0.10)$; ${ }^{*}, P<0.05$; **, $P<0.01$. s.e.m., standard error of least-squares means; Ca, calcium; P, phosphorus; Mg, magnesium; K, potassium; Na, sodium; AMGW, average mammary gland weight; B, Breed; R, feed restriction levels; D, gestation days

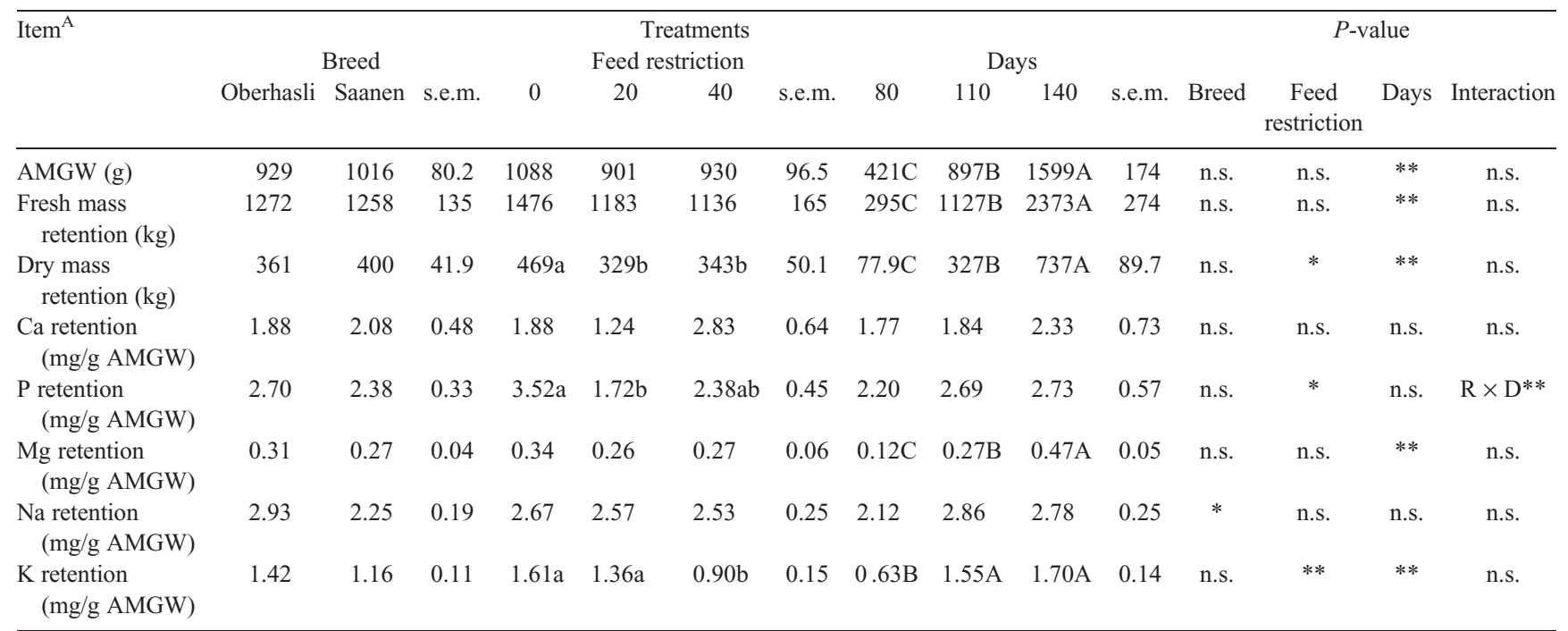

Table 7. Mineral retention in the femur of feed-restricted Oberhasli and Saanen goats at 80, 110 and 140 days of gestation a,b, Different letters on the same line indicate differences among feed restriction according to Tukey's test $(P<0.05)$. A,B, Different letters on the same line indicate differences among gestation days according to Tukey's test $(P<0.05)$. n.s., not significant $(P>0.10) ;{ }^{*}, P<0.05 ; * *, P<0.01$. s.e.m., standard error of least-squares means; Ca, calcium; P, phosphorus; Mg, magnesium; K, potassium; Na, sodium; AFW, average femur weight; B, Breed; R, feed restriction levels; D, gestation days

\begin{tabular}{|c|c|c|c|c|c|c|c|c|c|c|c|c|c|c|c|}
\hline \multirow[t]{2}{*}{ Item } & \multicolumn{11}{|c|}{ Treatments } & \multicolumn{4}{|c|}{$P$-value } \\
\hline & \multicolumn{3}{|c|}{ Breed } & \multicolumn{4}{|c|}{ Feed restriction } & \multicolumn{4}{|c|}{ Days } & & & & \\
\hline $\begin{array}{l}\text { Ca retention } \\
\quad(\mathrm{mg} / \mathrm{g} \text { AFW })\end{array}$ & -3.50 & 9.51 & 4.60 & 0.27 & 7.85 & 0.89 & 5.01 & 0.58 & 11.2 & -2.76 & 6.52 & * & n.s. & n.s. & n.s. \\
\hline $\begin{array}{l}\text { P retention } \\
\quad(\mathrm{mg} / \mathrm{g} \mathrm{AFW})\end{array}$ & -0.32 & 6.00 & 1.60 & 0.76 & 4.48 & 3.28 & 2.77 & $-0.58 \mathrm{~B}$ & $8.40 \mathrm{~A}$ & $0.70 \mathrm{~B}$ & 2.63 & $* *$ & n.s. & $* *$ & n.s. \\
\hline $\begin{array}{l}\text { Na retention } \\
\quad(\mathrm{mg} / \mathrm{g} \mathrm{AFW})\end{array}$ & 1.40 & 1.83 & 0.17 & 1.62 & 1.64 & 1.58 & 0.20 & 1.37 & 1.82 & 1.65 & 0.23 & 0.06 & n.s. & n.s. & n.s. \\
\hline $\begin{array}{l}\mathrm{K} \text { retention } \\
\quad(\mathrm{mg} / \mathrm{g} \mathrm{AFW})\end{array}$ & 0.04 & 0.03 & 0.05 & $0.03 \mathrm{ab}$ & $0.005 \mathrm{~b}$ & $0.07 \mathrm{a}$ & 0.09 & -0.02 & 0.14 & -0.01 & 0.08 & n.s. & * & n.s. & $\mathrm{B} \times \mathrm{R} \times \mathrm{D}^{* *}$ \\
\hline
\end{tabular}

evaluate the nutritional status of goats (Araújo et al. 2011), but these procedures do not indicate the feed restriction effects on bones, possibly because the femur is not the appropriate bone for that assessment. Bone resorption in response to the degree of feed restriction is detected initially in the first cervical vertebrae, pelvic bones, cranium and jaw (Benzie et al. 1956). These bones would therefore be better to analyse and evaluate bone resorption in response to feed restriction during critical periods such as pregnancy.

The negative retention of $\mathrm{Ca}$ that occurred in the $\mathrm{MB}$ after $40 \%$ feed restriction could be related to $\mathrm{Ca}$ mobilisation in order to ensure $\mathrm{Ca}$ deposition in the fetus even when serum $\mathrm{Ca}$ decreases during pregnancy. According to Kovacs (2003), maternal hypocalcemia does not compromise fetal development, which is maintained by adjustments in placental mechanisms for $\mathrm{Ca}$ uptake from $\mathrm{Ca}$-deficient maternal blood. Similarly, it was observed in sheep that fetal blood Ca levels exceed those of maternal blood from 35 days of gestation onward, and $\mathrm{Ca}$ is transferred to the fetus against a concentration gradient (Kovacs 2003). However, fetal mass growth was compromised under the most severe feed restriction despite maternal metabolism efforts. Therefore, our 



Fig. 1. (a) Serum calcium levels and (b) alkaline phosphatase activity $( \pm$ s.e.m. $)$ in dairy goats during pregnancy.

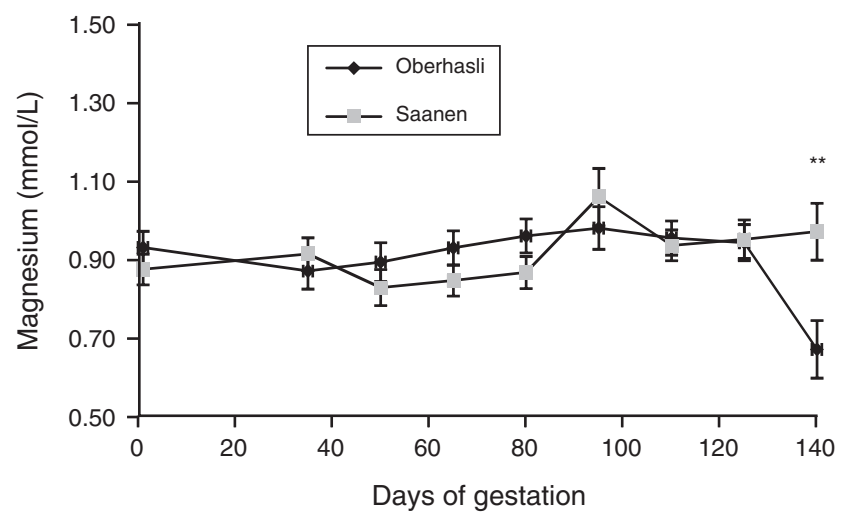

Fig. 2. Serum magnesium levels $( \pm$ s.e.m. $)$ in Oberhasli and Saanen goats during pregnancy. ${ }^{* *}, P<0.01$.

results are in agreement with other studies reporting that the MB under feed restriction cannot support normal fetal development (Scheaffer et al. 2001; Osgerby et al. 2002; Long et al. 2009).

The feed restriction imposed in the present study was not limited to minerals but also included other nutrients. Pregnancy is characterised by high energy demand, and the MB under feed deficiency mobilises reserves such as adipose and muscle tissue to meet the needs of the pregnant uterus (Bell and Ehrhardt 2000; Scheaffer et al. 2001). Under fasting or severe malnourishment conditions, the MB of ruminants undergoes gluconeogenesis using amino acids from muscle and glycerol from adipose tissue (Bell et al. 2005; Pethick et al. 2005; Kozloski et al. 2009). Gluconeogenesis is energetically expensive because it consumes six high-energy phosphate groups (4 adenosine triphosphate and 2 guanosine



Fig. 3. Serum potassium levels ( \pm s.e.m.) in Oberhasli and Saanen goats subjected to different feed restriction levels $(0 \%, 20 \%$ and $40 \%)$ during pregnancy. ${ }^{*}, P<0.05$.

triphosphate] to produce one glucose molecule from pyruvate (Lehninger et al. 2002). Therefore, $\mathrm{P}$ was possibly used for adenosine triphosphate formation in gluconeogenesis and low $\mathrm{P}$ amounts were available to the fetus and to the mammary gland of goats at $40 \%$ feed restriction.

Studies on sheep revealed that intrauterine feed restriction reduces the number of myofibrils formed in the fetus and DNA levels in the muscle, thereby decreasing postnatal growth (Greenwood et al. 2000; Estêvão et al. 2012). Therefore, we suggest that $\mathrm{P}$ reduction in the fetuses from goats at $40 \%$ of feed restriction may be related to the main cause of fetal growth delay observed, mainly due to the compromising of muscle development (Silva and Carvalho 2007). In addition, the higher retention of solids in the fetal fluid, exhibited in goats at $40 \%$ feed restriction, may be related to an inefficient nutrient use by the fetus. Given that, except for $\mathrm{Na}$, mineral retention in the fetal fluid was not changed in our study; glucose levels in the fetal fluid were negligible (Tabatabaei 2011), the fetuses of ewes under nutritional deprivation had decreased soft tissue development (Luther et al. 2007), and fat growth in the fetuses did not decrease (Nguyen et al. 2010), we suggest that the fetuses may have wasted amino acids; these wasted amino acids increased with feed restriction and were possibly the primary components of the extra dry mass of solids detected in the fetal fluid of goats at $40 \%$ feed restriction. Furthermore, under ordinary conditions, $\mathrm{Na}$ levels in the fetal fluid are considered an indicator of fetal metabolism because the onset of renal activity in the fetus increases $\mathrm{Na}$ retention, with a consequent reduction in $\mathrm{Na}$ levels in the fetal fluid (Pearson and Mellor 1977; Tabatabaei 2011). As such, increased $\mathrm{Na}$ in the fetal fluid as a response to feed restriction may indicate damage to fetal metabolic functions.

Despite $\mathrm{Na}$ and $\mathrm{K}$ mobilisation from the $\mathrm{MB}$, our results showed that the fetal $\mathrm{Na}$ and $\mathrm{K}$ accretion were not ensured and $\mathrm{K}$ retention in the mammary gland was also compromised. Therefore, we suggest that most of the $\mathrm{Na}$ and $\mathrm{K}$ obtained are likely used to meet maternal maintenance needs. In contrast to $\mathrm{Ca}, \mathrm{P}$ and $\mathrm{Mg}$, animals most likely do not have $\mathrm{Na}$ and $\mathrm{K}$ reserves, which are elements found abundantly in the diet 
(Ammerman and Goodrich 1983; Suttle 2010). In addition, during gestation $\mathrm{Na}$ and $\mathrm{K}$ are required for functions such as absorptive nutrient processes in both the digestive tract and placenta, and to maintenance of the acid-base balance in the body (Suttle 2010). Thus, with a severe decrease in dietary mineral supply, the MB lacks reserves that can overcome Na and $\mathrm{K}$ deficiency and may not be able to avoid deprivation of these minerals in the fetus and mammary gland.

Irrespective of the feed restriction level imposed, the goats in the present study mobilised the $\mathrm{Ca}, \mathrm{P}$ and $\mathrm{Mg}$ reserves accumulated at the beginning of pregnancy to meet uterus, fetal fluid, mammary gland, and in particular fetal nutrient demands. These results corroborate a study on dairy goats that reported a linear decrease in $\mathrm{Ca}, \mathrm{P}$ and $\mathrm{Mg}$ retention in the $\mathrm{MB}$ as a function of advancing pregnancy (Härter et al. 2015). Moreover, we observed that goat body composition and serum $\mathrm{Ca}$ levels indicate that mobilisation of maternal reserves meet the growth needs of gestation products. A drop in serum $\mathrm{Ca}$ levels had previously been reported in pregnant goats at a more advanced pregnancy stage (100 days) (Yildiz et al. 2005). Concomitantly, ALP activity decreased after 95 days of gestation, indicating a reduction in osteoblastic activity and possible bone resorption in the MB. Studies on pregnant Saanen goats have revealed that specific ALP activity in the bones decreases linearly with fetal development and that bone mineral density declines from the last month of gestation onward (Liesegang et al. 2007). In this respect, determination of ALP activity seems to be an effective, practical and inexpensive method to identify bone mineral resorption only in cases of significant mineral mobilisation. However, for small amounts of $\mathrm{Ca}$ and $\mathrm{P}$ resorption, as observed in comparisons between days of pregnancy, ALP activity was not suitable for indicating bone mineral resorption.

Serum $\mathrm{Mg}$ levels were lower in Oberhasli goats, possibly because of higher $\mathrm{Ca}$ and $\mathrm{P}$ retention in the MB. Magnesium is important for parathyroid hormone formation and the bone tissue response to parathyroid hormone (Kronqvist et al. 2011). Therefore, Saanen goats, which have greater $\mathrm{Ca}$ and $\mathrm{P}$ mobilisation, may require higher $\mathrm{Mg}$ levels for parathyroid hormone production, particularly at the end of gestation when the $\mathrm{Ca}$ demand for fetal bone formation and colostrum production is higher. These results may suggest that Oberhasli and Saanen goats have different efficiencies in their bone $\mathrm{Ca}$ resorption metabolism. Differences in $\mathrm{Mg}$ metabolism were also observed in different cattle breeds (Greene et al. 1989) and sheep breeds (Field et al. 1969).

Differences in Na retention in the MB were also observed between the breeds tested in our experiment. $\mathrm{Na}$ is known to participate in water metabolism control, and it exhibits a close relationship with renal water absorption (Suttle 2010). Although Oberhasli goats did not have a greater amount of water in their $\mathrm{MB}$, these goats had greater water amounts in the fetal fluid. Based on these observations we can suggest that these results may be related to adaptive adjustments of the Oberhasli goats' metabolism to different environments and more studies comparing the mineral metabolism of dairy goats are still needed.

Dairy goat breeds have been considered equally by international systems of animal feeding (NRC 2007).
However, the differences between the mineral metabolism of Saanen and Oberhasli breeds shown in the present study indicate that they must be considered separately in feeding management plans. Saanen goats have higher milk production but a lower total solids concentration in milk than Oberhasli goats under similar environmental conditions (Haenlein 1996). Thus, these breeds likely have different metabolic processes, but comparative studies are still needed to fully understand the mechanisms underlying the different responses.

\section{Conclusions}

In response to the reduction in feed intake, the MB uses its mineral reserves to maintain gestation. Goats subjected to $20 \%$ feed restriction still support fetal growth; however, at $40 \%$ feed restriction $\mathrm{P}, \mathrm{Na}$, and $\mathrm{K}$ fetal accretion is impaired.

\section{Acknowledgements}

The authors thank the São Paulo Research Foundation (FAPESP, grants \#2009/10125-0; 2007/58239-8) and the Coordenação de Aperfeiçoamento de Pessoal de Nível Superior (CAPES, grants 2400/11-1) for providing financial support.

\section{References}

Associação Brasileiras de Normas Tecnicas (ABNT) (2005) 'Aluminium and its alloys - extruded products - mechanical properties.' ABNT NBR 7000 : 2005 (ABNT: Rio de Janeiro, RJ, Brazil)

Ammerman CB, Goodrich RD (1983) Advances in mineral nutrition in ruminants. Journal of Animal Science 57, 519-533.

Araújo MJ, Medeiros AN, Teixeira IAMA, Costa RG, Baraldi FE, Artoni SM, Marques CAT, Resende KT (2011) Fêmur biometry, densitometry and chemical composition from Moxoto goats supplemented with concentrate in a semiarid region. Small Ruminant Research 97, 60-66. doi:10.1016/j.smallrumres.2011.02.012

Association of Official Analytical Chemists (AOAC) (1990) 'Official methods of analysis.' 15th edn. (AOAC: Arlington, VA)

Bell AW, Ehrhardt RA (2000) Regulation of macronutrient partitioning between maternal and conceptus tissues in the pregnant ruminant. In 'Ruminant physiology: digestion, metabolism, growth, and reproduction'. (Eds P Cronje, EA Boomker) pp. 275-294. (CABI International: Wallingford, UK)

Bell AW, Greenwood PL, Ehrhardt RA (2005) Regulation of metabolism and growth during prenatal life. In 'Biology of metabolism in growing animals. Vol. 3'. (Eds DG Burrin, HJ Mersmann) pp. 3-34. (Elsevier: Amsterdam)

Benzie D, Boyne AW, Dalgarno AC, Duckworth J, Hill R, Walker DM (1956) Studies of the skeleton of the sheep I. The relationship between calcium intake and resorption and repair of the skeleton in pregnancy and lactation. The Journal of Agricultural Science 48, 175-186. doi:10.1017/S0021859600030458

Breier BH (2006) Prenatal nutrition, fetal programming and opportunities for farm animal research. In 'Ruminant physiology. Digestion, metabolism and impact of nutrition on gene expression, immunology and stress'. (Eds K Sejrsen, T Hvelplund, MO Nielsen) pp. 347-362. (Wageningen Academic Publishers: Wageningen)

Demirtas B, Özcan M (2012) The effect of maternal undernutrition on muscle development in the ovine fetus. Turkish Journal of Veterinary and Animal Sciences 36, 297-303.

Devendra C (1999) Goats: challenges for increased productivity and improved livelihoods. Outlook on Agriculture 28, 215-226.

Estêvão MD, McKenzie SH, Ribeiro L, Tygesen MP, Sanchi T, Power DM (2012) Effect of maternal under-nutrition in late gestation on muscle 
and bone development in fetal sheep. Baltic Journal of Comparative and Clinical Systems Biology 1, 80-94.

Etheridge RD, Pesti GM, Foster EH (1998) A comparison of nitrogen values obtained utilizing the Kjeldahl nitrogen and Dumas combustion methodologies (Leco CNS 2000) on samples typical of an animal nutrition analytical laboratory. Animal Feed Science and Technology 73, 21-28. doi:10.1016/S0377-8401(98)00136-9

FAO (2005) 'FAO's animal production and health - livestock densities.' (Food and Agriculture Organization: Rome) Available at http://www.fao. org/Ag/againfo/resources/en/glw/Density_maps/goats_census-2005.jpg [Verified 20 November 2014]

Field AC, Weiner G, Wood J (1969) The concentration of minerals in the blood of genetically diverse groups of sheep. II. Calcium, phosphorus, magnesium, potassium, sodium and chloride concentrations for three hill-breeds and their crosses at pasture. The Journal of Agricultural Science 73, 267-274. doi:10.1017/S0021859600014477

Freitas VJF, Baril G, Saumandel J (1996) Induction and synchronization of estrus in goats: the relative efficiency of one versus two fluorogestone acetate-impregnated vaginal sponges. Theriogenology 46, 1251-1256. doi:10.1016/S0093-691X(96)00296-8

Fritz JS, Schenk GH (1979) 'Quantitative analytical chemistry.' 4th edn. (Allyn and Bacon: New York, NY)

Greene LW, Baker JF, Hardt PF (1989) Use of breeds and breeding to overcome the incidence of grass tetany: a review. Journal of Animal Science 67, 3463-3469.

Greenwood PL, Bell AW (2003) Prenatal nutrition influences on growth and development of ruminants. Recent Advances in Animal Nutrition in Australia 14, 57-73.

Greenwood PL, Hunt AS, Hermanson JW, Bell AW (2000) Effects of birth weight and postnatal nutrition on neonatal sheep: II. Skeletal muscle growth and development. Journal of Animal Science 78, 50-61.

Haenlein GFW (1996) Status and prospects of the dairy goat industry in the United States. Journal of Animal Science 74, 1173-1181.

Hafez ESE, Hafez B (2000) 'Reproduction in farm animals.' 7th edn. (Lippincott Williams and Wilkins: Philadelphia)

Härter CJ, Castagnino DS, Rivera AR, Lima LD, Silva HGO, Mendonça AN, Bonfim GF, Liesegang A, St-Pierre N, Teixeira IAMA (2015) Mineral metabolism in singleton and twin-pregnant dairy goats. AsianAustralasian Journal of Animal Sciences 28, 27-49.

Kovacs CS (2003) Fetal mineral homeostasis. In 'Pediatric bone: biology and diseases'. (Eds FH Glorieux, JM Pettifor, H Jüppner) pp. 271-302. (Academic Press: San Diego, CA)

Kozloski GV, Lima LD, Chiesa APR, Oliveira L, Fiorentini G, Härter CJ (2009) Net portal and visceral flux of metabolites in lambs fed rice-grass hay cut at different regrowth ages. Revista Brasileira de Zootecnia 38, 1114-1120. doi:10.1590/S1516-35982009000600020

Kronqvist C, Emanuelson U, Spörndly R, Holtenius K (2011) Effects of prepartum dietary calcium level on calcium and magnesium metabolism in periparturient dairy cows. Journal of Dairy Science 94, 1365-1373. doi:10.3168/jds.2009-3025

Laporte-Broux B, Roussel S, Ponter AA, Giger-Reverdin S, Camous S, Chavatte-Palmer P, Duvaux-Ponter C (2012) Long-term consequences of feed restriction during late pregnancy in goats on feeding behavior and emotional reactivity of female offspring. Physiology \& Behavior 106, 178-184. doi:10.1016/j.physbeh.2012.02.001

Lehninger AL, Nelson DL, Cox MM (2002) 'Principles of biochemistry.' 3rd edn. (Worth Publishers: New York, NY)

Liesegang A, Risteli J, Wanner M (2007) Bone metabolism of milk goats and sheep during second pregnancy and lactation in comparison to first lactation. Journal of Animal Physiology and Animal Nutrition 91, 217-225. doi:10.1111/j.1439-0396.2007.00695.x
Long NM, Vonnahme KA, Hess BW, Nathanielsz PW, Ford SP (2009) Effects of early gestational undernutrition on fetal growth, organ development, and placental composition in the bovine. Journal of Animal Science 87, 1950-1959. doi:10.2527/jas.2008-1672

Luther J, Aitken R, Milne J, Matsuzaki M, Reynolds L, Redmer D, Wallace J (2007) Maternal and fetal growth, body composition, endocrinology, and metabolic status in undernourished adolescent sheep. Biology of Reproduction 77, 343-350. doi:10.1095/biolreprod.107.061440

National Research Council (2007) 'Nutrient requirements of small ruminants. Sheep, goats, cervids and New World camelids.' 6th revised edn. (National Academy Press: Washington, DC)

Nguyen LT, Muhlhausler BS, Botting KJ, Morrison JL (2010) Maternal undernutrition alters fat cell size distribution, but not lipogenic gene expression, in the visceral fat of the late gestation guinea pig fetus. Placenta 31, 902-909. doi:10.1016/j.placenta.2010.07.014

Osgerby JC, Wathes DC, Howard D, Gadd TS (2002) The effect of maternal undernutrition on ovine fetal growth. The Journal of Endocrinology 173, 131-141. doi:10.1677/joe.0.1730131

Pearson RA, Mellor DJ (1977) Changes in fetal fluid composition during the last 60 days of gestation in goats. Journal of Reproduction and Fertility 50, 171-173. doi:10.1530/jrf.0.0500171

Pethick DW, Harper GS, Dunshea FR (2005) Fat metabolism and turnover. In 'Quantitative aspects of ruminant digestion and metabolism'. 2nd edn. (Eds J Dijkstra, JM Forbes, J France) pp. 345-371. (CAB International: Wallingford, UK)

Ritar AJ, Maxwell WCM, Salamon S (1984) Ovulation and LH secretion in the goat after intravaginalprogestogen sponge-PMSG treatment. Journal of Reproduction \& Infertility 72, 559-563. doi:10.1530/jrf.0. 0720559

Robertson JB, Van Soest PJ (1981) The detergent system of analysis and its application to human foods. In 'The analysis of dietary fiber in food'. (Eds WPT James, O Theander) pp. 123-158. (Marcel Dekker: New York, NY)

Scheaffer AN, Caton JS, Bauer ML, Reynolds P (2001) Influence of pregnancy on body weight, ruminal characteristics, and visceral organ mass in beef heifers. Journal of Animal Science 79, 2481-2490.

Silva MDP, Carvalho RF (2007) Cellular and molecular mechanisms that control muscular development and growth. Revista Brasileira de Zootecnia 36(special, supplement), 21-31. doi:10.1590/S1516-35982 007001000003

Suttle NF (2010) 'The mineral nutrition of livestock.' 4th edn. (Ed. NF Suttle) (CABI International: Wallingford, UK)

Tabatabaei S (2011) Gestational variations in the biochemical composition of the fetal fluids and maternal blood serum goat. Comparative Clinical Pathology 21, 1305-1312.

Teixeira IAMA, Resende KT, Silva AMA, Silva Sobrinho AG, Härter CJ, Sader APO (2013) Mineral requirements for growth of wool and hair lambs. Revista Brasileira de Zootecnia 42, 347-353. doi:10.1590/S15 16-35982013000500007

Trahair JF, DeBarro TM, Robinson JS, Owens JA (1997) Restriction of nutrition in utero selectively inhibits gastrointestinal growth in fetal sheep. The Journal of Nutrition 127, 637-641.

Van Soest PJ (1994) 'Nutritional ecology of the ruminant.' 2nd edn. (Cornell University Press: New York, NY) 476 pp.

Wilkens MR, Breves G, Schröder B (2014) A goat is not a sheep: physiological similarities and differences observed in two ruminant species facing a challenge of calcium homeostatic mechanisms. Animal Production Science 54, 1507-1511.

Yildiz A, Balikci E, Gurdogan F (2005) Serum mineral levels at pregnancy and postpartum in single and twin pregnant sheep. Biological Trace Element Research 107, 247-254. doi:10.1385/BTER:107:3:247 